\title{
Structure of the oviducal epithelium of the brush-tailed possum (Trichosurus vulpecula)
}

\author{
R. Arnold and C. D. Shorey \\ Department of Histology and Embryology, University of Sydney, New South Wales 2006, Australia
}

\begin{abstract}
Summary. Observations were made using scanning and transmission electron microscopy and were correlated with measurements of the mean surface area and the percentage area occupied by secretory cells to provide precise interpretation of the morphological data.

In cyclic and anoestrous possums the oviducts were lined with elaborate folds of mucosa except in the portion of the isthmus adjacent to the uterus where the pattern was much simplified. The folds decreased in height and number after ovariectomy. Secretion was maximal between oestrus and Day 2 of the cycle when most ovulations take place. Extrusion of vesicles was observed in the ampulla and isthmus at this stage although the process was localized to some extent because groups of cells with actively extruding vesicles were interspersed with others which contained vesicles but otherwise appeared inactive. This is interpreted as a device whereby a constant supply of secretion can be maintained over several days. Secretory activity declined between Days 3 and 8 and the epithelium in mid-cycle (Days 8-18) appeared relatively quiescent. By Day 24 there was morphological and morphometric evidence of a return to oestrous conditions, although vesicles had not yet reappeared in secretory cells. Ciliogenesis was prevalent at this time and is probably related to the ovum transport that will occur several days later.
\end{abstract}

\section{Introduction}

A considerable amount of information is available on the details of the surface morphology of the oviducts in a variety of eutherian species Kanagawa, Hafez, Pitchford, Baechler \& Barnhart, 1972; Stalheim, Gallagher \& Deyol, 1975; Ludwig \& Metzger, 1976; Jansen 1978; Hammer, Samarian \& Mitchell, 1978; Kessel \& Kardon, 1979; Busch, Kuhnel \& Mootz, 1981; Anderson, 1982) and transmission electron microscope (TEM) studies have been reported on at least one marsupial species (Hughes, 1974). However, no comprehensive scanning electron microscope (SEM) study of the marsupial reproductive tract has been published to date. The aim of this work is to report observations made with the SEM on the oviducts of brush-tailed possums, to correlate these with TEM observations and morphometry and to compare the results with those obtained from similar studies on eutherians.

The brush-tailed possum is an arboreal marsupial found in coastal regions of mainland Australia and Tasmania. It has adapted successfully to urban living and is a familiar inhabitant of many Australian cities. Adult females weigh 1-3 kg and are polyoestrous and monovular. The breeding season in the Sydney region extends from March to May. During this time the oestrous cycle lasts about 26 days; oestrus is taken as Day 0 of the cycle and is readily detected by means of vaginal smears (Hughes, 1962; Pilton \& Sharman, 1962). Ovulation occurs spontaneously between oestrus and Day 3 of the cycle with the majority of the animals ovulating on Day 2. After ovulation the ovum spends a single day in the oviduct. 


\section{Materials and Methods}

Animals and tissues. Female brush-tailed possums were trapped by means of treadle-operated cages placed throughout the Sydney metropolitan area. Oestrus was determined by taking daily vaginal smears according to the method described by Hughes (1962). Tissue samples for microscopy and image analysis were removed on Day 0 and on Days 3, 8, 13, 18 and 24 of the oestrous cycle. Two or three animals were used for each stage. Tissue for morphology and morphometry was also taken from one anoestrous animal and two that had been ovariectomized 4 and 14 months previously. Additional tissue for morphology was removed from 4 animals on each of Days 1 and 2 of the oestrous cycle and from 4 anoestrous animals.

The tissue was processed according to a standardized procedure which enabled quantitative comparisons between different stages to be carried out. Each oviduct was divided into infundibulum, ampulla and isthmus. The infundibulum was fixed for SEM by placing it mucosal side upwards in a generous amount of Karnovsky's fixative in 0.1 M-cacodylate buffer (Karnovsky, 1965). Pieces of tissue about $7 \mathrm{~mm}$ long were removed from the ampulla and isthmus and these were fixed for $30 \mathrm{~min}$ before lengthwise bisection. Pinning out the tissue during fixation (Ludwig \& Metzger, 1976) was avoided because volume changes resulting from the action of the fixative on the tissue can lead to distortion of cells between the pins (Boyde, Bailey, Jones \& Tamarin, 1977).

Tissue for SEM was fixed for $6 \mathrm{~h}$ at room temperature followed by several changes of buffer. The following day it was post-fixed in buffered $1 \%$ osmium tetroxide for $24 \mathrm{~h}$. This was followed by dehydration to $70 \%$ alcohol. Final dehydration and critical-point drying were completed within 2 weeks of fixation.

Small pieces of tissue for transmission electron microscopy were excised from each infundibulum and from the ampulla and isthmus immediately below the piece taken for SEM. These were fixed for $1 \mathrm{~h}$ in Karnovsky's fixative in $0.1 \mathrm{M}$-cacodylate buffer and post-fixed and embedded in the usual way.

Microscopy and image analysis. A sufficient number of areas to provide approximately 200 secretory cells for analysis were photographed from each piece of tissue at a magnification of about $\times 1000$. In addition, 10 photographs of each region of the oviduct were taken to determine the relative areas of the two cell types. Photographs were taken at approximately equal intervals over the entire tissue surface although damaged tissue was not used for morphometry. The precise magnification was determined by means of a calibration grating photographed at the same working distance as that used to photograph the specimens. A photograph of the grating was also used to calibrate the magnifications of the prints on which the image analysis was carried out.

Analysis was carried out using a Leitz semi-automatic image analyser interfaced with a HP9825B calculator and a HP2621P graphics plotter. Two different programmes were used. The first of these was designed to characterize changes in the mean surface area of secretory cells during the oestrous cycle and the second measured the total percentage area of each epithelial surface occupied by secretory cells.

The weighted pair-group average method of cluster analysis (Andenberg, 1973; Davis, 1973; Spath, 1980) was carried out on the results of the morphometric analysis to establish the relative importance of the differences between regions of the oviducts at a given stage of the oestrous cycle or changes within a given region at different stages of the cycle. Values being compared by cluster analysis are usually referred to as data units and each data unit must be characterized by a number of variables to enable the analysis to be carried out. The variables in this study were the mean area of secretory cells and the percentage area of epithelial surface occupied by them. The programme used was an adaptation of one published by Davis (1973). The adaptation involved translating the programme into Hewlett-Packard language and adding a plotting routine. This programme produces a symmetrical matrix relating each datum unit to every other datum unit by means of a measure of similarity such as the distance coefficient. The smaller the distance coefficient the more similar are the data units being compared. 


\section{Results}

Microanatomy of the mucosal surface

The infundibulum consisted of tall narrow folds whose inner surfaces were covered with mucosa which consisted of shallow close-packed wavy ridges (Pl. 1, Fig. 1). At the junction of the mucosa and serosa these ridges and folds decreased and were replaced fairly rapidly with the undulating surface of the serosa. Around the time of oestrus the infundibulum was usually folded around the ovary from which ovulation is to occur and often adhered quite firmly to it. This was not observed on the opposite side of the tract, at other stages of the oestrous cycle or in anoestrous animals.

A three-dimensional pattern of tight folds occurred at the junction of the infundibulum with the ampulla giving the mucosal surface a crumpled appearance (Pl. 1, Fig. 2). These continued throughout the ampulla and upper isthmus although the folds gradually decreased in complexity and height. In the lower isthmus the elaborate folds gave way to a large number of knob-like protrusions of mucosa separated by transverse indentations (P1. 1, Fig. 3).

Table 1. Results (mean \pm s.d.) of the morphometric analyses of the oviducal epithelium of brush-tailed possums during the oestrous cycle and anoestrus and after ovariectomy

\begin{tabular}{|c|c|c|c|}
\hline & Infundibulum & Ampulla & Isthmus \\
\hline \multicolumn{4}{|l|}{ Oestrus } \\
\hline $\mathrm{n}$ & 427 & 427 & 464 \\
\hline Area $\left(\mu \mathrm{m}^{2}\right)$ & $21 \cdot 6 \pm 10 \cdot 3$ & $19.1 \pm 11.9$ & $19 \cdot 0 \pm 10 \cdot 6$ \\
\hline$\%$ & $21 \cdot 0 \pm 6 \cdot 3$ & $56 \cdot 5 \pm 3 \cdot 4$ & $59 \cdot 0 \pm 4 \cdot 5$ \\
\hline \multicolumn{4}{|l|}{ Day 3} \\
\hline $\mathrm{n}$ & 236 & 253 & 254 \\
\hline Area $\left(\mu \mathrm{m}^{2}\right)$ & $20 \cdot 7 \pm 8 \cdot 7$ & $22 \cdot 4 \pm 9 \cdot 3$ & $23.4 \pm 10.6$ \\
\hline \multirow{2}{*}{\multicolumn{4}{|c|}{ Day 8}} \\
\hline & & & \\
\hline $\mathbf{n}$ & 617 & 436 & 282 \\
\hline Area $\left(\mu \mathrm{m}^{2}\right)$ & $29 \cdot 8 \pm 15 \cdot 0$ & $32 \cdot 2 \pm 13 \cdot 1$ & $33 \cdot 4 \pm 10 \cdot 7$ \\
\hline$\%$ & $22 \cdot 0 \pm 4 \cdot 2$ & $43 \cdot 5 \pm 2 \cdot 8$ & $52.5 \pm 11.3$ \\
\hline \multicolumn{4}{|l|}{ Day 13} \\
\hline $\mathrm{n}$ & 389 & 280 & 736 \\
\hline Area $\left(\mu \mathrm{m}^{2}\right)$ & $20 \cdot 8 \pm 8 \cdot 8$ & $16 \cdot 3 \pm 6 \cdot 8$ & $13 \cdot 9 \pm 5 \cdot 4$ \\
\hline$\%$ & $30 \cdot 0 \pm 0 \cdot 4$ & $37.0 \pm 1.4$ & $38.5 \pm 13.0$ \\
\hline \multicolumn{4}{|l|}{ Day 18} \\
\hline $\mathrm{n}$ & 294 & 387 & 149 \\
\hline Area $\left(\mu \mathrm{m}^{2}\right)$ & $26 \cdot 4 \pm 11 \cdot 4$ & $11 \cdot 5 \pm 4 \cdot 1$ & $8.9 \pm 3.6$ \\
\hline$\%$ & $23 \cdot 0 \pm 1 \cdot 0$ & $42.5 \pm 3.2$ & $21 \cdot 5 \pm 3 \cdot 2$ \\
\hline \multicolumn{4}{|l|}{ Day 24} \\
\hline $\mathrm{n}$ & 478 & 610 & 551 \\
\hline Area $\left(\mu \mathrm{m}^{2}\right)$ & $24 \cdot 7 \pm 12 \cdot 0$ & $18 \cdot 3 \pm 11 \cdot 2$ & $14 \cdot 2 \pm 7 \cdot 6$ \\
\hline$\%$ & $25 \cdot 5 \pm 2 \cdot 5$ & $71.5 \pm 11.5$ & $66.5 \pm 10.9$ \\
\hline \multicolumn{4}{|l|}{ Anoestrus* } \\
\hline $\mathrm{n}$ & 71 & 125 & 88 \\
\hline Area $\left(\mu \mathrm{m}^{2}\right)$ & $22 \cdot 1 \pm 11 \cdot 1$ & $23 \cdot 0 \pm 7 \cdot 5$ & $21 \cdot 0 \pm 6 \cdot 4$ \\
\hline$\%$ & $28 \cdot 5$ & $52 \cdot 0$ & 67.0 \\
\hline \multicolumn{4}{|l|}{$\begin{array}{l}\text { Ovariectomized } \\
4 \text { months* }\end{array}$} \\
\hline $\mathrm{n}$ & 221 & 92 & 76 \\
\hline Area $\left(\mu \mathrm{m}^{2}\right)$ & $14 \cdot 1 \pm 6 \cdot 4$ & $9 \cdot 8 \pm 3 \cdot 3$ & $9 \cdot 5 \pm 4.0$ \\
\hline$\%$ & $99 \cdot 0$ & 99.5 & 99.5 \\
\hline \multicolumn{4}{|l|}{14 months* } \\
\hline $\mathbf{n}$ & 247 & 217 & 207 \\
\hline Area $\left(\mu \mathrm{m}^{2}\right)$ & $12 \cdot 1 \pm 4 \cdot 8$ & $11 \cdot 0 \pm 3 \cdot 2$ & $8.7 \pm 3.7$ \\
\hline$\%$ & $98 \cdot 0$ & 99.5 & 99.5 \\
\hline
\end{tabular}

Area $=$ mean surface area of secretory cells.

$\%=$ percentage area of the epithelial surface occupied by secretory cells.

* Only 1 animal used. 
Morphology and morphometry of secretory cells

Oestrus to Day 2 of the oestrous cycle. At oestrus the mean surface area of the secretory cells was similar in all regions of the oviducts although they occupied a proportionally smaller percentage area of the epithelial surface in the infundibulum than in the ampulla and isthmus (Table 1). Secretory cells in the infundibulum occurred in small groups of 5 or 6 cells. They were slightly domed and TEM showed the presence of a few secretory vesicles in each cell which resembled those elsewhere in the oviducts. Cell surfaces were covered with short, fine, closely packed microvilli, sometimes with a single short cilium (Pl. 1, Fig. 4). Around the time of oestrus the junction of mucosa and serosa was well defined with large numbers of ciliated cells extending to the boundary with the serosa where they ceased abruptly. At other stages of the oestrous cycle numbers of ciliated cells decreased gradually and the junction with the serosa was less obvious.

Maximum secretory activity occurred between oestrus and Day 2 and extrusion of vesicles was observed in the ampulla and isthmus during this time. The secretory process was localized to some extent and the areas with extruding vesicles (Pl. 2, Figs $6 \& 7$ ) were separated by regions which appeared relatively inactive (Pl. 2, Fig. 8). Despite variations in the degree of extrusion of vesicles, light microscopy on semithin sections and TEM indicated that the secretory cells in actively extruding and inactive regions contained large numbers of vesicles (Pl. 1, Fig. 5). The actively secreting cells showed a range of surface structures. Many had a single very large dome devoid of microvilli and sufficiently tall to stand well above the level of the cilia. Domed apices were comparatively smooth or partly collapsed (Pl. 2, Fig. 7). Cells without large domes had one or several medium-sized cytoplasmic projections arising from their apices, sometimes with several blebs one on top of the other. There were also a number of membrane-bound vesicles free in the oviducal lumen. Smooth areas of the apical plasma membrane were punctured by small round indentations (Pl. 2, Fig. 7), which probably corresponded to the caveolae observed by TEM. TEM showed that the apical projections contained large numbers of individual secretory vesicles as well as a variable number of fused aggregates of two or more of these structures. Vesicles were also observed fused to the apical plasma membrane, sometimes bulging outwards from it. There were also apparently intact membranes in the lumen containing flocculent material similar to the contents of the intracellular vesicles. Secretory cells in the inactive areas had slightly domed surfaces covered with microvilli (Pl. 2, Fig. 8). About one-fifth of all the secretory cells in the ampulla and isthmus possessed a single cilium and this structure occurred even on cells with very large apical domes.

\section{PLATE 1}

Fig. 1. Mucosal surfaces of the infundibulum. $\times 50$.

Fig. 2. Mucosal surface of the ampulla. A similar pattern of folds is also present in the upper isthmus. $\times 160$.

Fig. 3. Mucosal surface of the lower isthmus. $\times 230$.

Fig. 4. The infundibulum at oestrus (Day 0 ). S, secretory cell; C, ciliated cell; cb, ciliary buds on cells undergoing ciliogenesis. $\times 1750$.

Fig. 5. Day 1 of the oestrous cycle. Apical region of a secretory cell in the ampulla. $\times 7500$.

\section{PLATE 2}

Figs $6 \& 7$. Day 1 of the oestrous cycle. Actively secreting cells in the isthmus. sv, secretory vesicle; sc, single cilium; $\Rightarrow$, caveola. Fig. $6, \times 2200$; Fig. $7, \times 6600$.

Fig. 8. Inactive region of the isthmus on Day 1. Note the small apical domes on the secretory cells $(S)$ and increased numbers of microvilli. $\times 2100$.

Fig. 9. Ampulla on Day 8 of the oestrous cycle. Secretory cells (S) have flat surfaces and boundaries are marked by a low ridge. sc, single cilium. $\times 220$. 
PLATE
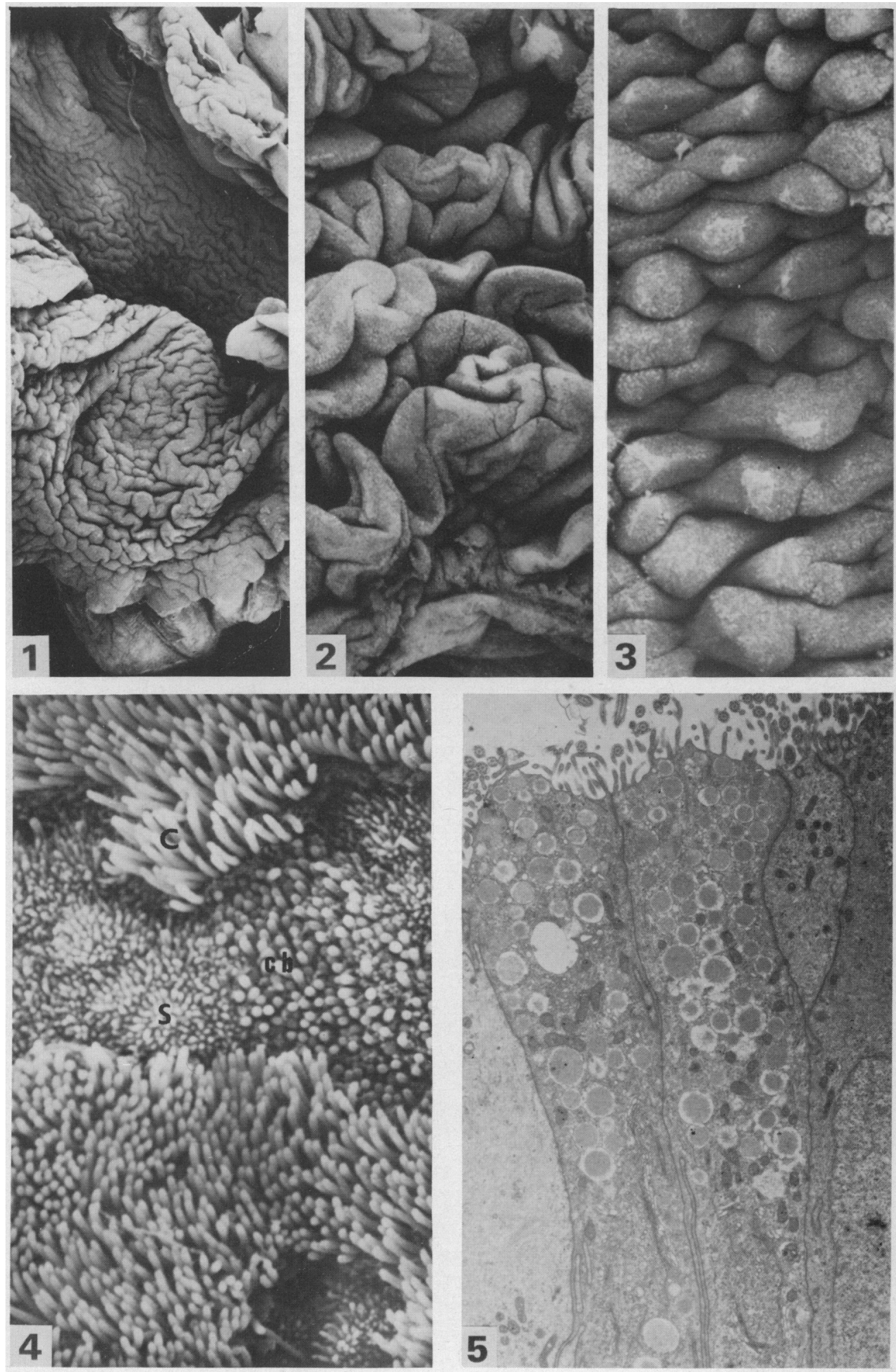

(Facing p. 12) 
PLATF. 2
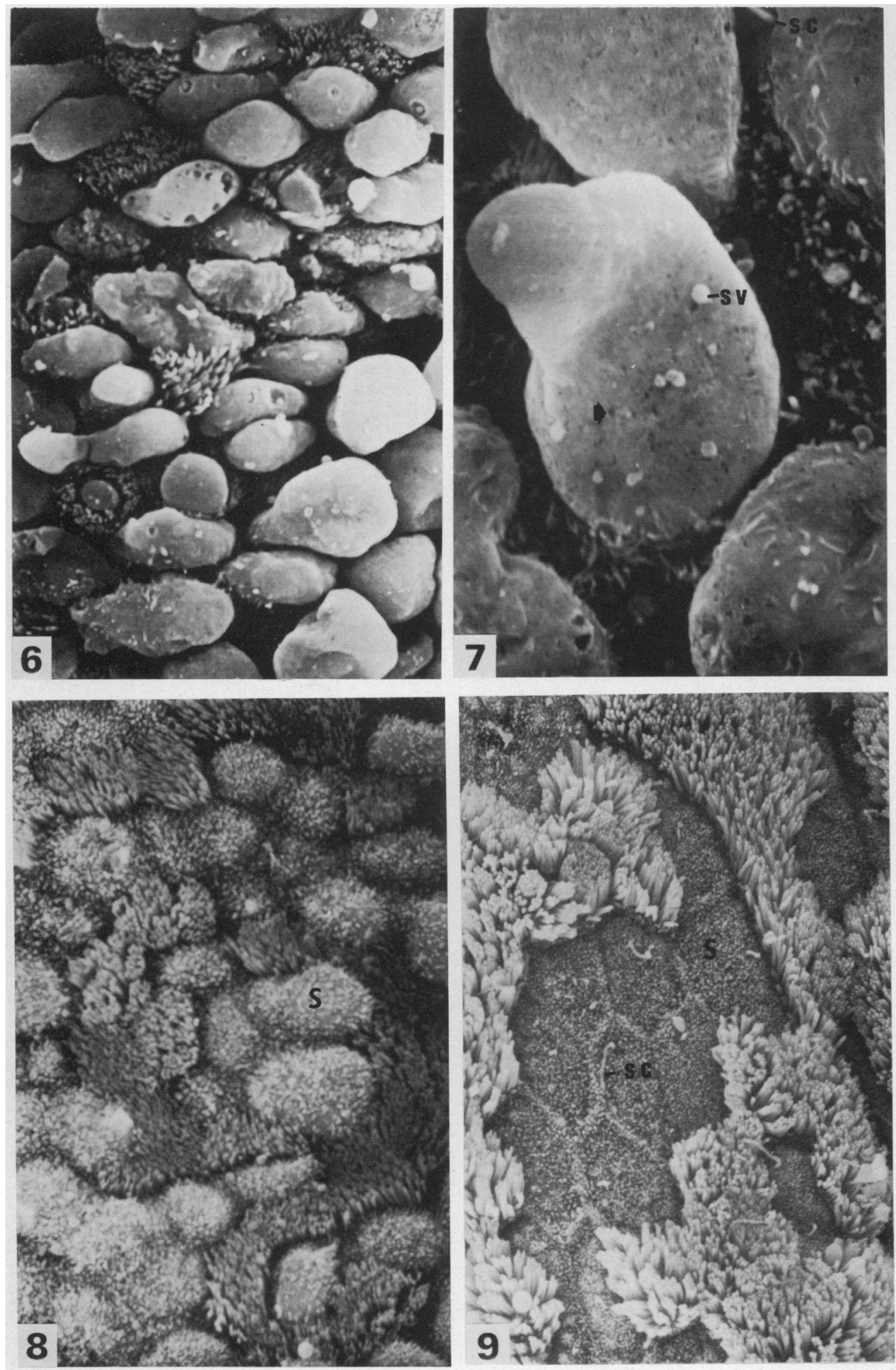

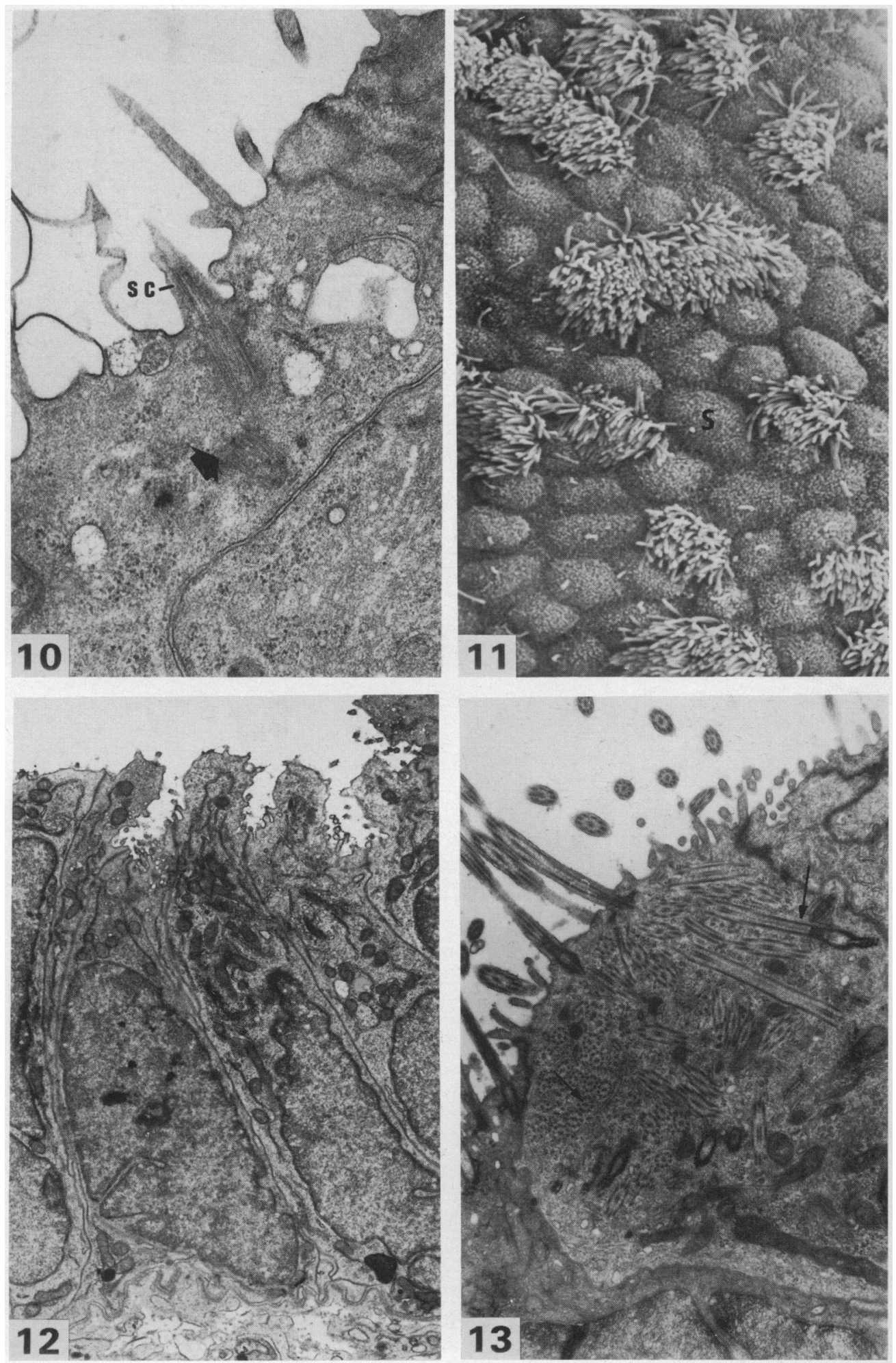
PLATE 4
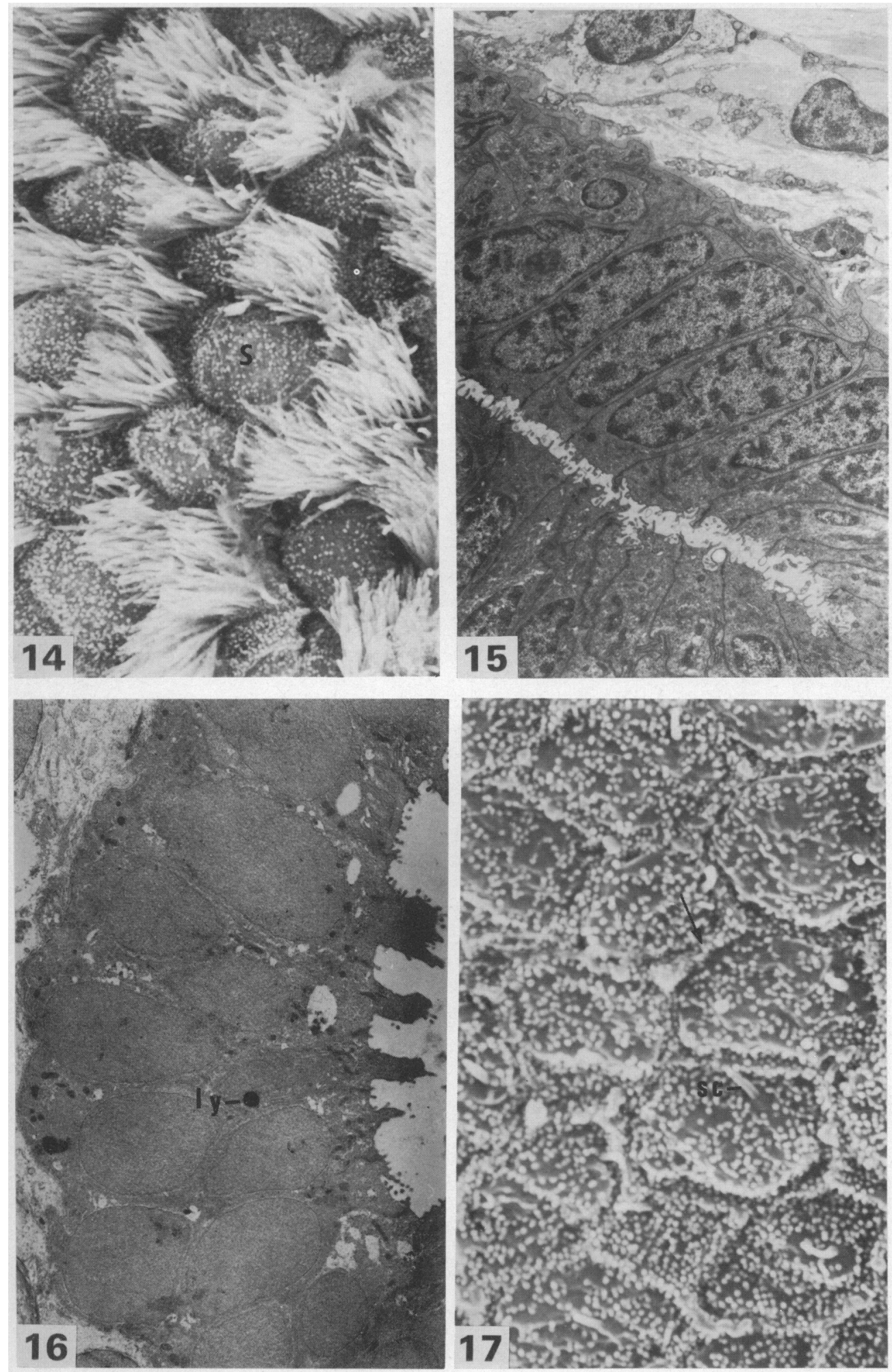
Day 3 of the oestrous cycle. Secretory activity decreased considerably on Day 3 of the oestrous cycle and the total percentage area of the surface occupied by the secretory cells in the ampulla and isthmus was reduced to about half when compared to values recorded at oestrus (Table 1). When viewed by SEM, secretory cells in the infundibulum on Day 3 resembled those at oestrus although light microscopy on semithin sections and TEM indicated that they no longer contained secretory vesicles.

Large secretory domes and cytoplasmic projections were not observed in the ampulla and isthmus on Day 3. This may be correlated to the partial depletion in vesicle content seen by TEM. However, mucus and membranous vesicles were still present in considerable numbers adhering to cilia or free in the lumen. Microvilli were usually sparse and caveolae were sometimes observed. A number of the secretory cells throughout the oviducts possessed a single cilium and these were also present in considerable numbers on Day 8 . The appearance of these structures was variable: some were very short and had a bulbous tip whereas others were of a length similar to that of the cilia of the ciliated cells (P1. 2, Fig. 9). These structures possessed an apparently normal axoneme but lacked the striated rootlet seen in ciliated cells. In some instances a single centriole was observed in close proximity to the single cilium ( $\mathrm{Pl}$. 3, Fig. 10). Pairs of centrioles were also commonly situated close to the apical plasma membrane.

Day 8 of the oestrous cycle. Mean area of secretory cells in all regions of the oviducts reached a maximum at this stage although secretory activity had all but ceased (Table 1). The percentage area of epithelial surface occupied by secretory cells also increased to a peak in the ampulla and isthmus (Table 1). Secretory cells in the infundibulum on Day 8 resembled those observed on Day 3. Elsewhere in the oviducts apical modifications indicative of secretory activity were absent and secretory cell surfaces were usually flat and densely covered with short, fine microvilli (P1. 2, Fig. 9). There were few, if any, secretory vesicles remaining within them and vesicles and mucus in the lumen were much less prevalent than on Day 3 of the cycle.

Day 13 of the oestrous cycle. Secretory cells in the three regions showed a small decrease in mean surface area at this stage and this may be correlated in the ampulla and isthmus with a decrease in percentage area of epithelium (Table 1). Secretory cells viewed by SEM were slightly domed rather than flat but otherwise had the surface morphology noted on Day 8. Intracellular secretory vesicles were never observed at this stage although a few membranous remnants persisted in the oviducal lumen.

\section{PLATE 3}

Fig. 10. Single cilium (sc) on Day 8. Arrow indicates adjacent centriole. $\times 4500$.

Fig. 11. Ampulla on Day 24 of the oestrous cycle, showing domed secretory cells (S). $\times 1500$. Fig. 12. Secretory cells from the isthmus on Day 24. Organelles are plentiful but secretory vesicles are still absent. $\times 4400$.

Fig. 13. Ciliogenesis on Day 24. Note basal bodies and axonemes $(\rightarrow)$ in apical cytoplasm as well as mature cilia on apex of cell. $\times 19200$.

\section{PLATE 4}

Fig. 14. Isthmus during anoestrus. Secretory cells (S) have flat surfaces or are slightly domed and microvilli are relatively sparse. $\times 2200$.

Fig. 15. Ampulla during anoestrus. There are few organelles and secretory vesicles were never observed. $\times 2600$.

Fig. 16. Isthmus 14 months after ovariectomy. ly, lysosomes. $\times 3000$.

Fig. 17. Isthmus 14 months after ovariectomy. Microvilli are short and sparse and all secretory cells possess a single cilium (sc). Note peripheral ridge of cytoplasm $(\rightarrow) \times 7300$. 
Day 18 of the oestrous cycle. The oviducts were shorter and narrower on Day 18 than at any other stage of the oestrous cycle. Small fluctuations of secretory cell area and percentage area, similar in magnitude to those noted at earlier stages of the oestrous cycle, occurred in the infundibulum (Table 1). Mean secretory cell area continued to decrease in the ampulla and isthmus (Table 1). However the percentage area occupied by secretory cells increased slightly in the ampulla but decreased sharply in the isthmus (Table 1). This was the only stage at which measurements for ampulla and isthmus showed noticeable divergence from each other.

The secretory cells in the infundibulum on Day 18 were usually flat surfaced and cell boundaries were sometimes difficult to distinguish by SEM. Most cells appeared to have an angular outline with the apical surface covered with long microvilli. Cells in the remainder of the oviducts were rounded or ovoid and apical surfaces were covered with short microvilli. There was a variable degree of apical doming although intracellular secretory vesicles were absent.

Day 24 of the oestrous cycle. By Day 24 the mean surface area of the secretory cells in the three regions was similar to that measured at oestrus (Table 1). Values for percentage area were more variable: the area occupied by secretory cells in the infundibulum was similar to that at oestrus whereas those recorded for ampulla and isthmus were higher than the oestrous values (Table 1). Many secretory cells at this stage showed a greater degree of apical doming than was usual at midcycle (Pl. 3, Fig. 11). However, secretory vesicles were not observed by light microscopy on semithin sections or with TEM (Pl. 3, Fig. 12). Secretory cells possessing a single cilium were more common on Day 24 than at mid-cycle.

Anoestrus. The surface area of secretory cells was similar in all regions of the oviducts and they occupied an increasing percentage of the epithelial surface from infundibulum to isthmus (Table 1). There were morphological similarities between the epithelium of the oviducts during anoestrus and that at mid-cycle. The secretory cells in the infundibulum were usually flat-surfaced and densely covered with microvilli which were often thicker individually than those in cyclic animals. Secretory cells elsewhere in the oviducts showed a variable degree of doming and were sparsely covered with very short microvilli (Pl. 4, Fig. 14). Secretory vesicles were not observed in any region of the oviducts and organelles were sparse (Pl. 4, Fig. 15). A number of cells possessed a single cilium and in others a pair of centrioles was positioned adjacent to the apical plasma membrane.

After ovariectomy. By 4 months after ovariectomy the length of the oviducts was reduced to about $25 \%$ of the size observed at oestrus and the lumen was considerably narrowed. A further reduction in length and diameter occurred by 14 months after ovariectomy. In both animals the mean surface area of secretory cells in all regions of the oviducts was less than was usual in intact animals and secretory cells occupied $99 \%$ of the epithelial surface (Table 1).

The secretory cells contained relatively few organelles. There was a large pale nucleus and electron-dense structures of various sizes which were probably lysosomes. These appeared to be less prevalent in the animal ovariectomized 14 months previously (Pl. 4, Fig. 16). The cell surfaces after ovariectomy were flat or slightly domed and possessed very short scattered microvilli which increased in number towards the cell boundaries. By 14 months after ovariectomy cell surfaces were crumpled rather than flat and microvilli were further reduced in numbers (PI. 4, Fig. 17). Cells outlines were marked by a peripheral ridge which was sometimes prominent above the level of the central portion of the cell. All the secretory cells observed at both stages possessed a single cilium.

\section{Morphology and morphometry of ciliated cells}

Ciliated cells in the possum oviducts underwent little morphological change during the oestrous cycle although ciliogenesis may occur at some stages. Their apical surfaces were covered in long closely packed cilia which obscured most other surface detail including boundaries separating individual cells (Pl. 1, Fig. 4; Pl. 2, Figs 6 \& 8). The cilia were interspersed with long fine microvilli. 
Ciliogenesis, as indicated by the presence of ciliary buds, occurred on a minority of cells in the infundibulum at oestrus (Pl. 1, Fig. 4) but was not observed elsewhere in the oviducts at this stage. Cells undergoing ciliogenesis were occasionally observed in the infundibulum between Days 3 and 15 but not on Day 18. Day 24 was the only stage of the oestrous cycle when ciliogenesis was observed throughout the oviducts. Cellular apices covered in ciliary buds of various lengths interspersed with microvilli were particularly prevalent in the infundibulum but also occurred singly or in groups in the ampulla and isthmus. Aggregations of dense granules, each $40-50 \mathrm{~nm}$ in diameter, were present in some cells and others contained an array of basal bodies. Basal bodies close to the apical surface were usually randomly arranged rather than aligned beneath the plasma membrane. Many possessed a well developed intracellular axoneme. Both the basal body and the axoneme were indistinguishable in terms of filament number and orientation from the mature cilia protruding from cell surfaces (Pl. 3, Fig. 13).

Ciliated cells continued to be plentiful in anoestrous animals. They were densely covered with cilia and resembled those in cyclic animals. An occasional cell undergoing ciliogenesis was observed in the infundibulum of some animals. Ciliated cells were rare after ovariectomy. When present, these occurred singly or less commonly in groups of two or three. Cilia on individual cells were usually more widely separated than in intact animals and some cells had cilia on only part of the apical surface.

\section{Morphometric analysis}

Cluster analysis was carried out on variables obtained from animals during the oestrous cycle (Table 1; Text-figs $1 \& 2$ ). It was apparent from Text-fig. 1 that considerable differences in the variables existed between oestrus and Day 3 of the cycle, coinciding with the time during which maximum secretion occurs. This is also indicated in the linkage tables (Text-fig. 2) in which oestrus and Day-3 values were correlated at the end of the linkage process, indicating a large degree of
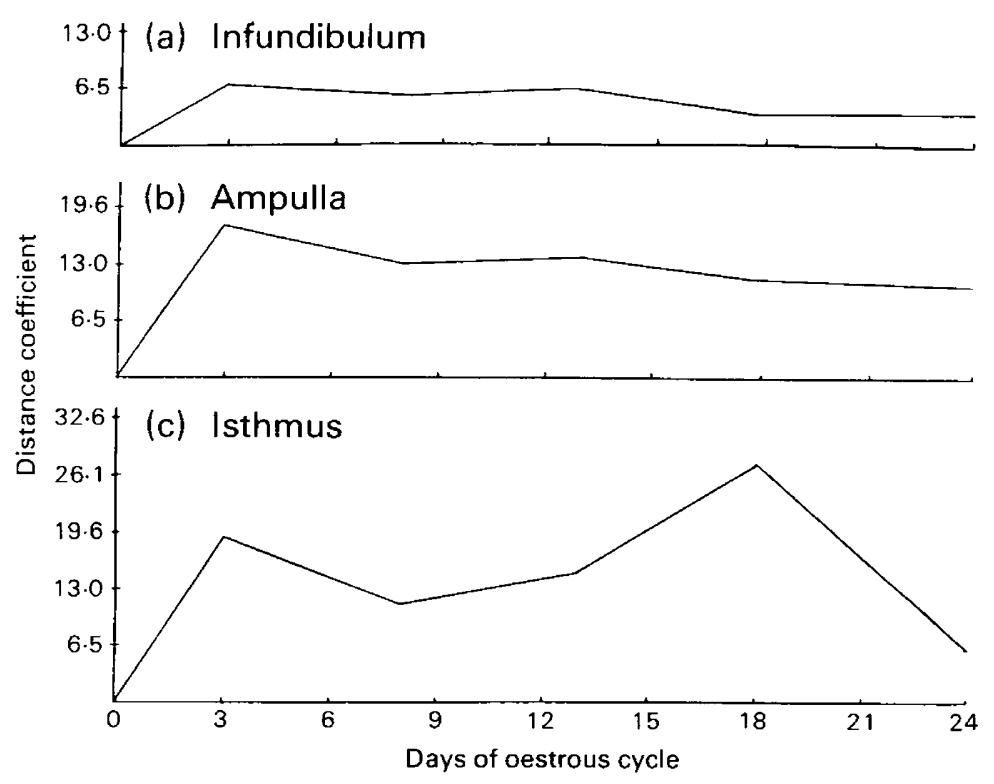

Text-fig. 1. Distance coefficients for single regions of the oviducts comparing values for each stage of the cycle with those at oestrus, i.e. these graphs illustrate changes in each region during the oestrous cycle. 


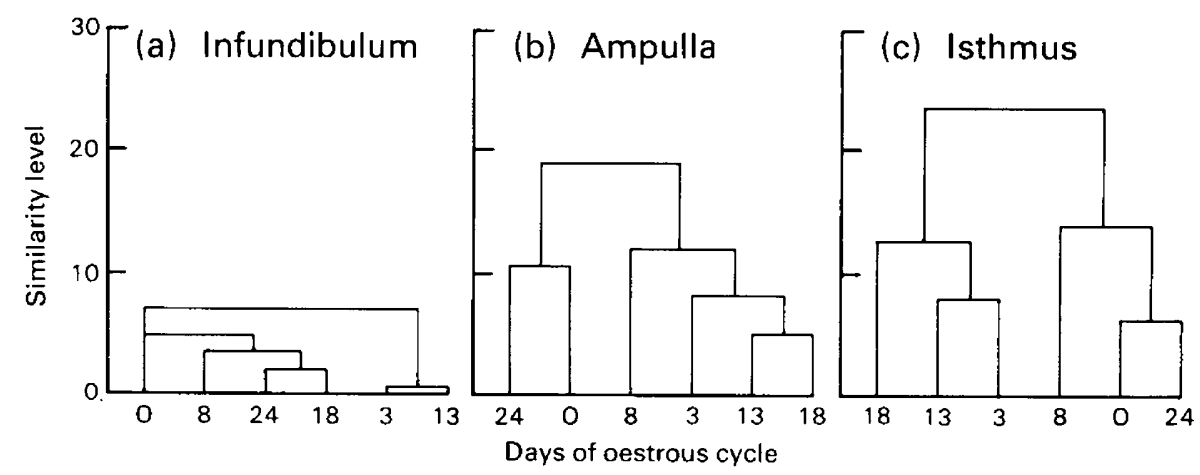

Text-fig. 2. Dendrograms derived from linkage tables obtained from the distance coefficients for each region of the oviducts. These dendrograms link the most similar stages of the cycle first, followed by linkage of regions of greater difference. $\mathrm{O}=$ day of oestrus.

difference. Divergence from the oestrous condition increased in magnitude along the oviducts with distance coefficients being the smallest in the infundibulum (Text-fig. 1a) and greatest in the isthmus (Text-fig. 1c). Despite the difference in magnitude, the pattern of fluctuation of distance coefficients was similar in the three regions with the exception of the isthmus on Day 18 for which a very large distance coefficient was recorded (Text-fig. 1c). Distance coefficients for the other two regions at this stage were decreasing (Text-figs la \& b).

\section{Discussion}

The most obvious change in the infundibulum was recorded between oestrus and Day 3 and was mainly the result of extensive ciliogenesis around the time of oestrus. Distance coefficients on Days 8 and 13 were similar to those of Day 3, indicating that there is no major change in the infundibulum at these times. However, some fluctuations in individual variables were noted. Maximum mean surface area was recorded on Day 8 (Table 1) followed by a decline on Day 13 when progesterone is maximal (Table 1) (Shorey \& Hughes, 1971). This pattern was observed in other regions of the oviducts and may be related to the increased levels of circulating progesterone. Concentrations of circulating oestrogen have not been reported for mid-cycle in this species and the influence of this hormone on morphometric fluctuations is unknown. Distance coefficients on Days 18 and 24 of the oestrous cycle were small, indicating an incipient return to oestrous morphology.

Ciliogenesis occurred sporadically in the infundibulum during the oestrous cycle and was prevalent throughout the oviducts just before oestrus when levels of oestrogen are increasing (Thorburn, Cox \& Shorey, 1971): ciliogenesis in eutherians is oestrogen dependent (Brenner, 1970). The groups of dense granules observed were morphologically identical with the proliferative elements described by Dirksen \& Crocker (1965) in the mouse and Brenner (1970) in the rhesus monkey. The presence of these presumed proliferative elements is an indication that basal body formation in developing ciliated cells followed a pattern similar to that described for eutherians (Dirksen \& Crocker, 1965; Dirksen, 1971). However, intracellular development of axonemes does not appear to have been described in eutherians.

With regard to the origin of ciliated cells in the oviducts of the possum, undifferentiated cells have never been reported in mature oviducts and at appropriate stages of the oestrous cycle all nonciliated cells contained secretory vesicles. Developing ciliated cells in the possum were not observed to contain vesicles although this sometimes occurs in the rabbit (Marchant, 1969). However, vesicles did appear in ciliated cells in intact or ovariectomized animals treated with large 
doses of oestradiol benzoate (Hughes, 1974). This was interpreted by Hughes (1974) as granulation of existing ciliated cells but could equally have been ciliogenesis of secretory cells because ciliogenesis is oestrogen-dependent in most species (Brenner, 1970; Verhage, Bareither, Jaffe \& Akbar, 1979; Odor, Gaddum-Rosse, Rumery \& Blandau, 1980). In either case, the concurrent presence of granules and cilia are an indication, as they are in the rabbit, that at least some of the cells are multipotential and that ciliated cells may arise as a result of redifferentiation of existing secretory cells.

The ampulla and isthmus were similar at all stages of the oestrous cycle with the exception of Day 18. Distance coefficients indicated that these regions underwent considerable changes during the first 3 days of the cycle (Text-figs $1 b \& 1 c$ ). This was mainly the result of a large decrease in the total epithelial surface occupied by secretory cells and not to a decrease in the mean surface area. Ciliogenesis was not observed at this stage and mitotic activity, especially amongst ciliated cells, was very low, so the addition of large numbers of ciliated cells to the pre-existing population can be discounted as a factor in the altered cell ratio. The remaining possibility, a change in the surface area of ciliated cells, could not be tested as many boundaries were obscured by cilia.

Mean surface area increased on Day 8 to a maximum in both regions despite the fact that granules had become very sparse, but decreases were recorded on Day 13 when levels of progesterone were maximal (Shorey \& Hughes, 1971). Distance coefficients for the ampulla and isthmus diverged widely on Day 18 of the oestrous cycle, due mainly to a considerable decrease in the total area of isthmic epithelium occupied by secretory cells. The discrepancy is difficult to explain, especially since the mean size of secretory cells in both regions was similar. Some parity in distance coefficients for the two regions was restored on Day 24 of the cycle.

It is not possible to state whether the presence of active and inactive regions of secretion in the ampulla and isthmus is typical of marsupials in general, as descriptions of species other than the possum are restricted to light microscope observations. However, this does not seem to occur in the eutherian species examined to date. This may be a device whereby large amounts of secretion can be produced rapidly without premature depletion of the entire stock of vesicles. It is also possible that individual cells may produce several batches of secretion between oestrus and Day 2 or 3 of the cycle, with inactive phases to allow for replenishment of vesicles. A constant supply of secretion seems to be important in the possum in which ovulation can occur at oestrus or on any one of the following 3 days (Pilton \& Sharman, 1962).

There is no information available on the process of ovum transport in the possum, but the extremely tortuous nature of the folds along most of the length of the oviducts indicates that they are unlikely to play an important part in directing the ovum towards the uterus as the straight folds in the ampulla of the rabbit appear to do (Patton \& Halbert, 1979). It is more likely that they are a device to increase surface area and to bring the cilia into intimate contact with the ovum. The importance of ciliary action in ovum transport in the brush-tailed possum was indicated by the fact that ciliogenesis only occurs in the ampulla and isthmus just before ovulation.

The elaborate pattern of folds continues until the lower isthmus and this indicates that if ovum transport is interrupted at the ampullary-isthmic junctions, as it is in some eutherians such as the rabbit (Boling \& Blandau, 1971), then it is unlikely to be the result of the fold pattern.

Major involution of mucosal folds or the epithelium covering them was not observed in anoestrous possums although reproductive tract involution has been reported outside the breeding season in some other marsupial species (Woolley, 1966). However, this is consistent with the brushtailed possum having two breeding seasons per year and with the work of Pilton \& Sharman (1962) who regarded the time outside the breeding season as a very attenuated oestrous cycle rather than a truly anoestrous condition. The percentage area of epithelium occupied by ciliated cells in anoestrous oviducts appeared to fall within the range noted in cyclic animals and this indicated that at least a small amount of oestrogen remains in circulation (Brenner, 1970).

The initial effects of ovariectomy on the oviducts appeared more rapidly in this particular marsupial species than in the eutherian species described in the literature (Brenner, 1970; Rumery 
\& Eddy, 1974). One of the more obvious results was a reduction in the number of ciliated cells and Hughes (1974) has described this as being well underway 28 days after ovariectomy, whereas deciliation does not seem to occur to any great extent in eutherians until several months have elapsed (Brenner, 1970). However, as in eutherians (Rumery \& Eddy, 1974), the process of involution is a long one and the presence of lysosomes in cells 14 months after ovariectomy indicate that it may be incomplete even at this stage.

It has been suggested that the single cilia are residual structures on formerly fully-ciliated cells (Anderson \& Brenner, 1971) but this is unlikely because every cell observed after ovariectomy possessed this structure and this is considerably greater than even the highest percentage of ciliated cells in the intact animal. It is probable that these structures arise from one of the cell's centrioles since the other centriole was often seen in close proximity to the cilium if the section was favourable. Ciliated centrioles have not been observed in oviduct tissues but have been described for many other organs (Scherft \& Daems, 1967; Gallagher, 1980).

We thank Dr S. Bradbury, Human Anatomy, Oxford, for statistical help.

\section{References}

Andenberg, M.R. (1973) Cluster Analysis for Applications. Academic Press, New York.

Anderson, R.G.W. \& Brenner, R.M. (1971) The formation of basal bodies (centrioles) in the rhesus monkey oviduct. J. Cell Biol. 50, 10-34.

Anderson, T.L. (1982) Changes in the uterine luminal cell surface during early pseudopregnancy in rabbits. Anat. Rec. 202, 7A, Abstr.

Boling, J.L. \& Blandau, R.J. (1971) Egg transport through the ampullae of the oviducts of rabbits under various experimental conditions. Biol. Reprod. 4, 174-184.

Boyde, A., Bailey, E., Jones, S.J. \& Tamarin, A. (1977) Dimensional changes during specimen preparation for scanning electron microscopy. In Scanning Electron Microscopy, 1977, Vol. 1, pp. 507-517. Ed. O. Johari. SEM Inc., Chicago.

Brenner, R.M. (1970) Hormonal control of cilia renewal in the primate oviduct; ultrastructural studies. In Progress in Gynecology, Vol. 5, pp. 77-97. Eds S. Sturgis \& E. Taymore. Grune and Stratton, New microscopy. J. Cell Biol. 727, 137A, Abstr.

Busch, L.C., Kuhnel, W. \& Mootz, V. (1981) Scanning electron microscopical studies of the rabbit endometrium during estrus and preimplantation. In Three Dimensional Microanatomy of Cells and Tissue Surfaces, pp. 267-278. Eds L. J. A. diDio, P. M. Motta \& J. J. Allen. Elsevier/North Holland, Amsterdam.

Davis, J.C. (1973) Statistics and Data Analysis in Geology. John Wiley and Sons, New York.

Dirksen, E.R. (1971) Centriole morphogenesis in the developing ciliated epithelium of the mouse oviduct. J. Cell Biol. 51, 286-302.

Dirksen, E.R. \& Crocker, T.T. (1965) Centriole replication in differentiating ciliated cells of mammalian respiratory epithelium: an electron microscopical study. J. Microscopie 5, 629-644.

Gallagher, B.C. (1980) Primary cilia of the corneal endothelium. Am. J. Anat. 159, 475-484.

Hammer, R.E., Samarian, R. \& Mitchell, J.A. (1978) Alterations in scanning electron microscopy of the uterine epithelium of the rat, effects of ovarian steriod hormones. In Scanning Electron Microscopy, 1978, Vol. 1, pp. 701-706. Ed. O. Johari. SEM Inc., Chicago.

Hughes, R.L. (1962) Role of the corpus luteum in marsupial reproduction. Nature, Lond. 194, 890-891.

Hughes, R.L. (1974) The tertiary egg membranes of the marsupial Trichosurus vulpecula. Ph.D. thesis, University of New South Wales.

Jansen, R.P.S. (1978) Fallopian tube mucus and ovum transport. Science, N.Y. 201, 349-351.

Kanagawa, H., Hafez, E.S.E., Pitchford, W.C., Baechler, C.A. \& Barnhart, M.I. (1972) Surface patterns of the reproductive tract of the rabbit observed by scanning electron microscopy. Anat. Rec. 174, 205-226.

Karnovsky, M.J. (1965) A formaldehyde-glutaraldehyde fixative of high osmolarity for use in electron microscopy. J. Cell Biol. 727, 137A, Abstr.

Kessel, R.G. \& Kardon, R.H. (1979) A Text Atlas of Scanning Electron Microscopy. W. H. Freeman and Co., San Francisco.

Ludwig, H. \& Metzger, H. (1976) The Human Female Reproductive Tract. Springer-Verlag, Berlin.

Marchant, H. (1969) Secretory granules in ciliated cells of the rabbit oviduct. Expl Cell Res. 56, 171-172.

Odor, D.L., Gaddum-Rosse, P., Rumery, R.E. \& Blandau, R.J. (1980) Cyclic changes in the oviductal ciliated cells during the menstrual cycle and after oestrogen treatment in the pig-tailed monkey Macaca nemestrina. Anat. Rec. 198, 35-57.

Patton, D.L. \& Halbert, S.A. (1979) Electron microscopic examination of the rabbit oviductal ampulla following microsurgical end-to-end anastomosis. Fert. Steril. 32, 691-696.

Pilton, P.E. \& Sharman, G.B. (1962) Reproduction in the marsupial Trichosurus vulpecula. J. Endocr. 25, 119136.

Rumery, R.E. \& Eddy, M. (1974) Scanning electron microscopy of the fimbrae and ampullae of rabbit oviducts. Anat. Rec. 178, 83-101.

Scherft, J.P. \& Daems, W.T. (1967) Single cilia in chondrocytes. J. Ultrastr. Res. 19, 546-555.

Shorey, C.D. \& Hughes, R.L. (1971) Cyclic changes in the 
uterine endometrium and peripheral plasma concentrations of progesterone in the marsupial Trichosurus vulpecula. Aust. J. Zool. 21, 1-19.

Spath, M. (1980) Cluster Analysis Algorithms for Data Reduction and Classification. John Wiley and Sons, New York.

Stalheim, O.V.H., Gallagher, J.E. \& Deyol, B.L. (1975) Scanning electron microscopy of the bovine, porcine and caprine uterine tubes. Am. J, vet. Res. 36, 10691075.

Thorburn, G.D., Cox, R.I. \& Shorey, C.D. (1971) Ovarian steroid secretion rates in the marsupial Trichosurus vulpecula. J. Reprod. Fert. 24, 139, Abstr.

Verhage, H.G., Bareither, M.L., Jaffe, R.C. \& Akbar, M. (1979) Cyclic changes in ciliation, secretion and secretory cell height of the oviductal epithelium in women. Am. J. Anat. 156, 505-522.

Woolley, P. (1966) Reproduction in Antechinus spp. and other dasyurid marsupials. Symp. zool. Soc. Lond. 15, 281-294.

Received 31 January 1984 